\title{
The role of IL-23 in the immunopathogenesis of psoriasis
}

\section{Paola Di Meglio and Frank O Nestle*}

\author{
Address: St John's Institute of Dermatology, King's College London School of Medicine; NIHR Biomedical Research Centre; and FOCIS Centre of \\ Excellence at King's College London, London SE1 9RT, UK \\ * Corresponding author: Frank O Nestle (frank.nestle@kcl.ac.uk) \\ FI000 Biology Reports 2010, 2:40 (doi:I0.34I0/B2-40)
}

The electronic version of this article is the complete one and can be found at: http://fl000.com/reports/biology/content/2/40

\begin{abstract}
In just 10 years from its discovery in 2000, interleukin-23 has quickly moved from being recognized as a pro-inflammatory cytokine to a key player and potential therapeutic target in psoriasis.
\end{abstract}

\section{Introduction and context}

Interleukin-23 (IL-23) is a heterodimeric cytokine, consisting of a unique IL-23p19 subunit paired with a common IL-12/23p40 subunit, which is shared with IL-12 [1]. It is mainly produced by activated myeloid cells, as well as epithelial and endothelial cells, and signals through its heterodimeric IL-23 receptor complex, consisting of a unique IL-23 receptor (IL-23R) subunit paired with a common IL-12R $\beta 1$ subunit shared with the IL-12 receptor complex (Figure 1) [2]. Shortly after its discovery, IL-23 emerged as a key pro-inflammatory cytokine driving autoimmunity, in both animal models and human diseases. In mice, lack of IL-23 was found to make them resistant to animal models of arthritis and multiple sclerosis $[3,4]$. In addition, models of experimental colitis pointed towards a role for IL-23 as a key tissue-specific effector cytokine that amplifies the inflammatory response $[5,6]$. In humans, IL-23 was found to be over-expressed in clinical samples of several immune-mediated diseases, including Crohn's disease, rheumatoid arthritis and multiple sclerosis. At the same time, IL-23 was strongly implicated in the development of a novel, IL-17A-producing Thelper (Th) 17 cell subset, which had just been discovered and identified as a main player in autoimmunity [7].

These findings have set the scene for a major reevaluation of the immunopathogenesis of psoriasis. Psoriasis is a T-cell-mediated, chronic inflammatory skin disease that results from a complex interplay between environmental and genetic factors [8]. Psoriasis had been traditionally regarded as a Th1-type and tumor necrosis factor (TNF)-driven disease but this perception was challenged after the discovery of IL-23 and experimental and clinical data that put the spotlight on the IL-23/Th17 axis in psoriasis.

Intradermal injection of IL-23 or over-expression of IL-12/23p40 in mouse keratinocytes (KCs) was shown to lead to erythema, induration and prominent dermal papillary blood vessels with histopathological features resembling psoriasis $[9,10]$. IL-23 was found to be highly expressed in psoriatic skin lesions, where it is mainly produced by tissue-resident and/or recruited dendritic cells (DCs) with some possible contribution by KCs $[11,12]$. Moreover, the clinical benefit from conventional and biologic systemic therapies targeting psoriasis was found to correlate with IL-23 down-regulation in psoriatic patients $[13,14]$, and a proof-of-concept phase I study testing efficacy and safety of ustekinumab, a human monoclonal antibody directed against IL12/ 23p40, showed promising results in the treatment of moderate to severe psoriasis [15]. Consistently, IL-17A was shown to be expressed in psoriatic skin [9], suggesting that Th17 cells could possibly infiltrate psoriatic lesions, contributing to chronic inflammation.

\section{Major recent advances}

In the past 3 years major advances in our understanding of psoriasis pathogenesis have arisen from exciting genetic, immunological and clinical findings, all unambiguously converging on the pivotal role of the IL-23/ Th17 axis in psoriasis [16] . 
Figure I. Interleukin-23 and its receptor complex

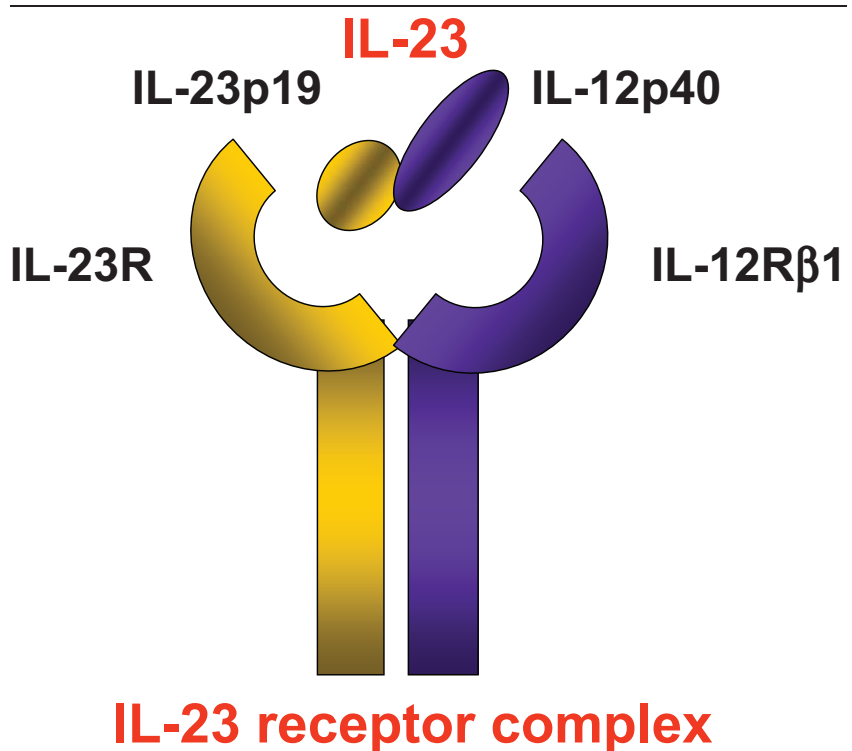

Interleukin (IL)-23 is a heterodimeric cytokine composed of IL-12/23p40 and IL-23pI 9 subunits. It binds to the IL-23 receptor complex composed of IL-I2RßI and IL-23R subunits.

Genome-wide association studies have clearly and repeatedly shown that several genes of the IL-23 pathway are associated with psoriasis. We and others have found that single nucleotide polymorphisms in both the IL12B and IL23R genes, coding for IL-12/23p40 and IL23R subunits, respectively, are associated with psoriasis $[17,18]$. Of interest, the non-synonymous nucleotide substitution in the IL23R gene, resulting in an arginine to glutamine exchange (Arg381Gln) in the cytoplasmic domain of the receptor, has a protective role not only in psoriasis, but also in other immune-mediated diseases, including Crohn's disease [19], suggesting that genetic variants in the IL23R gene might be common determinants of autoimmunity. Finally, a genetic association with psoriasis has recently been found also for variants in the IL23A gene, which codes for the IL-23p19 subunit [20].

Human Th17 cells have been thoroughly characterized with respect to their cytokine requirements (transforming growth factor-beta plus one of several pro-inflammatory cytokines, i.e., IL-6, IL-1 $\beta$, IL-23 and IL-21), lineage markers (master regulator transcription factor ROR $\gamma t$ and surface markers CCR6 and IL-23R) and cytokine production (IL-17A, but also IL-17F, IFN- $\gamma$, IL22 and IL-26) [21,22]. Likewise, the role of IL-23 with regard to Th17 cell biology has been clarified and refined. Although not required for early Th17 development, IL-23 plays a role in terminal differentiation of effector Th17 cells and their pathogenicity in peripheral tissues [23]. These findings are of relevance to psoriasis as Th17 cells have been identified in psoriatic skin [24] and Th17 cytokines have been found to be expressed at high levels in lesional skin and to induce the production of antimicrobial peptides and chemokines by KCs [21]. Of particular interest is the link between IL-23 and IL-22 production by Th 17 cells. IL-23 injection in mice induces IL-22-dependent dermal inflammation, KC hyperproliferation and epidermal acanthosis [25], while IL-22 neutralization is able to prevent the development of psoriasiform skin lesions [26]. Moreover, CCR6 also seems to be required for IL-23-induced and IL-22mediated psoriasis-like skin inflammation in mice [27], and it has been shown that Th17 cytokines can stimulate the production of the CCR6 ligand CCL20 by KCs, suggesting a possible mechanism by which Th17 cells maintain their continual presence in psoriatic skin [28]. Therefore, in the 'IL-23/Th17 axis' model of psoriasis, IL-23 secreted by dermal DCs is able to induce Th17 cell activation and the release of pro-inflammatory Th17 cytokines that acts on KCs, which, in turn, sustain and amplify the chronic inflammatory disease process by producing more IL-23 as well as pro-inflammatory cytokines, chemokines, members of the $\mathrm{S} 100$ family and antimicrobial peptides (e.g., TNF, IL-8, CCL-20, S100 molecules, defensins and cathelicidins; Figure 2).

The anti-IL-12/IL-23 monoclonal antibody ustekinumab has been approved in Canada (December 2008), Europe (January 2009) and USA (September 2009) for human use in moderate to severe psoriasis. Designed in the late 1990s with the aim of blocking IL-12 (IL-23 was still unknown at that time), ustekinumab targets the common IL-12/23p40 subunit, thus blocking both IL-12 and IL-23 signalling. Phase 3 clinical trials (Phoenix 1 and Phoenix 2) involving more than 2000 patients have shown that up to $76 \%$ of patients achieve at least a $75 \%$ improvement in the Psoriasis Area and Severity Index (PASI 75) at week 24, with only mild and non-serious adverse events $[29,30]$. Very recently, ustekinumab has shown higher efficacy than the anti-TNF drug etanercept, with $71 \%$ of patients in the high-dose ustekinumab group achieving PASI 75 compared to $49 \%$ in the etanercept group after 12 weeks. Interestingly, up to $49 \%$ of the non-responders in the etanercept group had a PASI 75 response when crossed over to high-dose ustekinumab [31].

\section{Future directions}

IL-23 represents one of the rare instances in which basic science has rapidly progressed to preclinical studies and resulted in a clinical intervention that supports the 
Figure 2. The interleukin (IL)-23/ThI7 axis in the immunopathogenesis of psoriasis

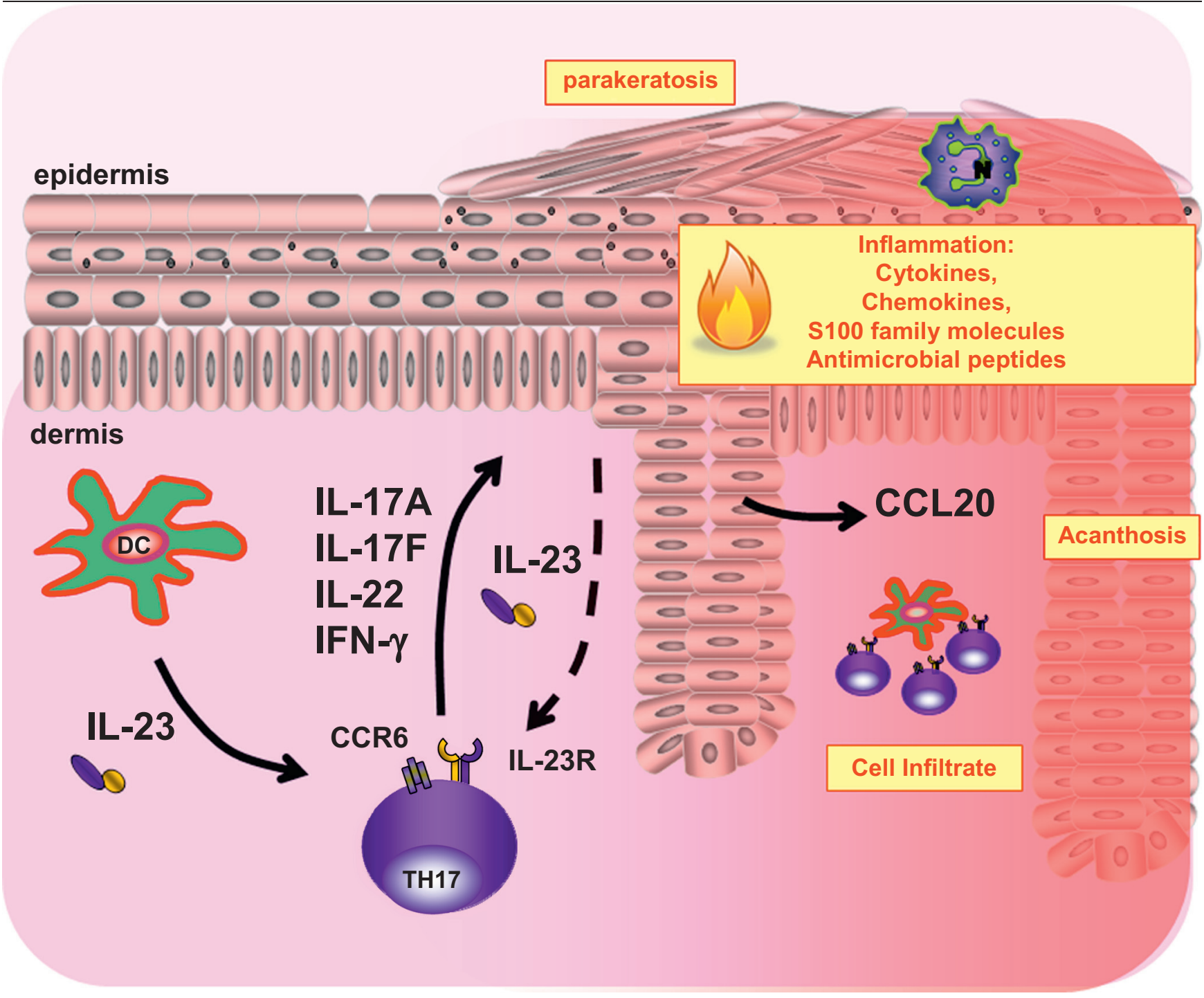

In the 'IL-23/ThI7 axis' model of psoriasis, T helper 17 (ThI7) cells interact with skin-resident cells, contributing to the psoriatic disease phenotype, characterized by scaly plaques and thickened epidermis (acanthosis), with elongated rete ridges and hyperproliferative keratinocytes (KCs) retaining the nucleus in the stratum corneum (parakeratosis), as well as dermal inflammatory cell infiltrate. IL-23 secreted by dermal dendritic cells (DCs) is able to induce ThI7 cell activation with production of pro-inflammatory cytokines such as IL-I7A, IL-I7F, IL-22 and IFN- $\gamma$. These cytokines act on KCs, inducing epidermal hyperplasia and KC activation. Activated KCs produce pro-inflammatory mediators, including chemokines, members of the SI00 family, pro-inflammatory cytokines and antimicrobial peptides. In particular, CCL20 is able to recruit more CCR6+ ThI7 cells. Moreover, KCs might produce IL-23, which could mediate crosstalk with ThI7 cells in synergy with IL-23 produced by dermal DCs, thus further sustaining and amplifying skin inflammation.

efficacy of IL-23/IL-12 targeting in the treatment of psoriasis. However, several questions remain to be answered. First, what is the functional role of the IL-23 pathway gene variants associated with psoriasis? Second, is there any correlation between these genetic variants and disease phenotype? Third, are the newly discovered genetic variants of any use in pharmacogenetic studies to predict treatment response?
Moreover, a recently described Th cell subset, IL-22producing Th22 cells, has been identified in psoriasis [32]. It will be interesting to investigate if IL-23 plays a role in Th22 activation in psoriasis. Finally, the ultimate question is whether inhibition of IL-23 on its own, with either monoclonal antibodies or small molecules, is effective. Clinical studies to test the safety and effectiveness of a monoclonal anti IL-23 are currently under way 
and will provide us with useful new insights into the role of IL-23 in the immunopathogenesis of psoriasis.

\section{Abbreviations \\ DC, dendritic cell; IL, interleukin; IL-23R, IL-23 receptor; KC, keratinocyte; PASI, Psoriasis Area and Severity Index; Th, T helper; TNF, tumor necrosis factor.}

\section{Competing interests}

FON has provided consultant advice to Centocor Inc. (Horsham, PA, USA), Abbott Laboratories (Abbot Park, IL, USA) and Janssen Cilag (High Wycombe, Buckinghamshire, UK). PDM declares that she has no competing interests.

\section{Acknowledgments}

We acknowledge support from the following grant funding bodies: Wellcome Trust, National Institutes of Health, National Institute for Health Research (NIHR) Comprehensive Biomedical Research Centre at Guy's and St Thomas' Hospital and King's College London, Medical Research Council UK, Dunhill Medical Trust and Wyeth Pharmaceuticals' Advances in Psoriasis Research Grant Programme Award.

\section{References}

I. Oppmann B, Lesley R, Blom B, Timans JC, Xu Y, Hunte B, Vega F, Yu N, Wang J, Singh K, Zonin F, Vaisberg E, Churakova T, Liu M, Gorman D, Wagner J, Zurawski S, Liu Y, Abrams JS, Moore KW, Rennick D, de Waal-Malefyt R, Hannum C, Bazan JF, Kastelein RA: Novel p 19 protein engages IL-I 2 p40 to form a cytokine, IL23, with biological activities similar as well as distinct from IL-1 2. Immunity 2000, 13:7| 5-25.

2. Parham C, Chirica M, Timans J, Vaisberg E, Travis M, Cheung J, Pflanz S, Zhang R, Singh KP, Vega F, To W, Wagner J, O'Farrell AM, McClanahan T, Zurawski S, Hannum C, Gorman D, Rennick DM, Kastelein RA, de Waal Malefyt R, Moore KW: A receptor for the heterodimeric cytokine IL-23 is composed of IL-I2Rbetal and a novel cytokine receptor subunit, IL-23R. J Immunol 2002, 168:5699-708.

3. Murphy CA, Langrish $\mathrm{CL}$, Chen $\mathrm{Y}$, Blumenschein $\mathrm{W}, \mathrm{McClanahan} \mathrm{T}$, Kastelein RA, Sedgwick JD, Cua DJ: Divergent pro- and antiinflammatory roles for IL-23 and IL- 12 in joint autoimmune inflammation. J Exp Med 2003, 198: 195।-7.

FI000 Factor 6.0 Must Read

Evaluated by Casey Weaver 07 Jul 2004

4. Cua DJ, Sherlock J, Chen Y, Murphy CA, Joyce B, Seymour B, Lucian L, To W, Kwan S, Churakova T, Zurawski S, Wiekowski M, Lira SA, Gorman D, Kastelein RA, Sedgwick JD: Interleukin-23 rather than interleukin- 12 is the critical cytokine for autoimmune inflammation of the brain. Nature 2003, 421:744-8.

FI000 Factor 4.8 Must Read

Evaluated by Marie Kosco-Vilbois 12 Mar 2003, Paul Lyons 04 Apr 2003

5. Uhlig HH, McKenzie BS, Hue S, Thompson C, Joyce-Shaikh B, Stepankova R, Robinson N, Buonocore S, Tlaskalova-Hogenova H, Cua DJ, Powrie F: Differential activity of IL-12 and IL-23 in mucosal and systemic innate immune pathology. Immunity 2006, 25:309-18.

FI000 Factor 6.0 Must Read

Evaluated by Steve Ward 02 Oct 2006
6. Hue S, Ahern P, Buonocore S, Kullberg MC, Cua DJ, McKenzie BS, Powrie F, Maloy KJ: Interleukin-23 drives innate and $\mathbf{T}$ cellmediated intestinal inflammation. J Exp Med 2006, 203:2473-83.

7. Langrish $\mathrm{CL}$, Chen $\mathrm{Y}$, Blumenschein WM, Mattson J, Basham B, Sedgwick JD, McClanahan T, Kastelein RA, Cua DJ: IL-23 drives a pathogenic $\mathbf{T}$ cell population that induces autoimmune inflammation. J Exp Med 2005, 20 I:233-40.

FI000 Factor 6.0 Must Read

Evaluated by Casey Weaver 09 Feb 2005

8. Nestle FO, Kaplan DH, Barker J: Psoriasis. N Engl J Med 2009, 36I:496-509.

9. Chan JR, Blumenschein W, Murphy E, Diveu C, Wiekowski M, Abbondanzo S, Lucian L, Geissler R, Brodie S, Kimball AB, Gorman DM, Smith K, de Waal Malefyt R, Kastelein RA, McClanahan TK, Bowman EP: IL-23 stimulates epidermal hyperplasia via TNF and IL-20R2-dependent mechanisms with implications for psoriasis pathogenesis. J Exp Med 2006, 203:2557-87.

FI000 Factor 3.0 Recommended

Evaluated by Richard Locksley 05 Dec 2006

10. Kopp T, Lenz P, Bello-Fernandez C, Kastelein RA, Kupper TS, Stingl G: IL-23 production by cosecretion of endogenous p I9 and transgenic p40 in keratin 14/p40 transgenic mice: evidence for enhanced cutaneous immunity. I Immunol 2003, 170:5438-44.

II. Lee E, Trepicchio WL, Oestreicher JL, Pittman D, Wang F, Chamian F, Dhodapkar M, Krueger JG: Increased expression of interleukin 23 pl9 and p40 in lesional skin of patients with psoriasis vulgaris. J Exp Med 2004, 199: 125-130.

12. Piskin G, Sylva-Steenland RM, Bos JD, Teunissen MB: In vitro and in situ expression of IL-23 by keratinocytes in healthy skin and psoriasis lesions: enhanced expression in psoriatic skin. J Immunol 2006, 176:1908-15.

13. Piskin G, Tursen U, Sylva-Steenland RM, Bos JD, Teunissen MB: Clinical improvement in chronic plaque-type psoriasis lesions after narrow-band UVB therapy is accompanied by a decrease in the expression of IFN-gamma inducers - IL-I2, IL-I 8 and IL-23. Exp Dermatol 2004, I3:764-72.

14. Gottlieb AB, Chamian F, Masud S, Cardinale I, Abello MV, Lowes MA, Chen F, Magliocco M, Krueger JG: TNF inhibition rapidly downregulates multiple proinflammatory pathways in psoriasis plaques. J Immunol 2005, I75:272I-9.

15. Kauffman CL, Aria N, Toichi E, McCormick TS, Cooper KD, Gottlieb AB, Everitt DE, Frederick B, Zhu Y, Graham MA, Pendley CE, Mascelli MA: A phase I study evaluating the safety, pharmacokinetics, and clinical response of a human IL-I 2 p40 antibody in subjects with plaque psoriasis. J Invest Dermatol 2004, I 23:1037-44.

16. Di Cesare A, Di Meglio P, Nestle FO: The IL-23/ThI7 axis in the immunopathogenesis of psoriasis. J Invest Dermatol 2009, 129:1339-50.

17. Capon F, Di Meglio P, Szaub J, Prescott NJ, Dunster C, Baumber L, Timms K, Gutin A, Abkevic V, Burden AD, Lanchbury J, Barker JN, Trembath RC, Nestle FO: Sequence variants in the genes for the interleukin-23 receptor (IL23R) and its ligand (ILI2B) confer protection against psoriasis. Hum Genet 2007, I 22:20I-6.

18. Cargill M, Schrodi S), Chang M, Garcia VE, Brandon R, Callis KP, Matsunami N, Ardlie KG, Civello D, Catanese J], Leong DU, Panko JM, McAllister LB, Hansen CB, Papenfuss J, Prescott SM, White TJ, Leppert MF, Krueger GG, Begovich AB: A large-scale genetic association study confirms ILI 2B and leads to the identification of IL23R as psoriasis-risk genes. Am J Hum Genet 2007, 80:273-90.

FI000 Factor 9.0 Exceptional

Evaluated by Grant Morahan 16 Jan 2007

19. Duerr RH, Taylor KD, Brant SR, Rioux JD, Silverberg MS, Daly MJ, Steinhart AH, Abraham C, Regueiro M, Griffiths A, Dassopoulos T, Bitton A, Yang H, Targan S, Datta LW, Kistner EO, Schumm LP, 
Lee AT, Gregersen PK, Barmada MM, Rotter JI, Nicolae DL, Cho JH: A genome-wide association study identifies IL23R as an inflammatory bowel disease gene. Science 2006, 3 I4: I46 I-3.

FI000 Factor 4.8 Must Read

Evaluated by Mark Anderson 19 Dec 2006, Paul Lyons 2I Dec 2006

20. Nair RP, Duffin KC, Helms C, Ding J, Stuart PE, Goldgar D, Gudjonsson JE, Li Y, Tejasvi T, Feng BJ, Ruether A, Schreiber S, Weichenthal M, Gladman D, Rahman P, Schrodi SJ, Prahalad S, Guthery SL, Fischer J, Liao W, Kwok PY, Menter A, Lathrop GM, Wise CA, Begovich AB, Voorhees JJ, Elder JT, Krueger GG, Bowcock AM, Abecasis GR; Collaborative Association Study of Psoriasis: Genome-wide scan reveals association of psoriasis with IL-23 and NF-kappaB pathways. Nat Genet 2009, 4I:199204.

21. Wilson NJ, Boniface K, Chan JR, McKenzie BS, Blumenschein WM, Mattson JD, Basham B, Smith K, Chen T, Morel F, Lecron JC, Kastelein RA, Cua DJ, McClanahan TK, Bowman EP, de Waal Malefyt R: Development, cytokine profile and function of human interleukin 17-producing helper T cells. Nat Immunol 2007, 8:950-7.

FI000 Factor 8.0 Exceptional Evaluated by Dale Umetsu 19 Sep 2007, Steve Ward 24 Sep 2007

22. Manel N, Unutmaz D, Littman DR: The differentiation of human $\mathrm{T}(\mathrm{H})$ - I7 cells requires transforming growth factor-beta and induction of the nuclear receptor RORgammat. Nat Immunol 2008, 9:64I-9.

23. McGeachy MJ, Chen $Y$, Tato CM, Laurence A, Joyce-Shaikh B, Blumenschein WM, McClanahan TK, O'Shea J], Cua DJ: The interleukin 23 receptor is essential for the terminal differentiation of interleukin 17-producing effector $T$ helper cells in vivo. Nat Immunol 2009, 10:314-24.

24. Lowes MA, Kikuchi T, Fuentes-Duculan J, Cardinale I, Zaba LC, Haider AS, Bowman EP, Krueger JG: Psoriasis vulgaris lesions contain discrete populations of ThI and ThI7 T cells. J Invest Dermatol 2008, I 28: I207-II.

25. Zheng Y, Danilenko DM, Valdez P, Kasman I, Eastham-Anderson I, Wu J, Ouyang W: Interleukin-22, a $\mathbf{T}(\mathbf{H})$ I7 cytokine, mediates IL-23-induced dermal inflammation and acanthosis. Nature 2007, 445:648-5I.

FI000 Factor 8.4 Exceptional

Evaluated by Steve Ward 14 Feb 2007, Steven Rosenberg 16 Feb 2007, Ruth Roberts 21 Mar 2007, James Campbell 03 May 2007

26. Ma HL, Liang S, Li J, Napierata L, Brown T, Benoit S, Senices M, Gill D, Dunussi-Joannopoulos K, Collins M, Nickerson-Nutter C, Fouser LA, Young DA: IL-22 is required for ThI 7 cell-mediated pathology in a mouse model of psoriasis-like skin inflammation. J Clin Invest 2008, I I 8:597-607.

27. Hedrick MN, Lonsdorf AS, Shirakawa AK, Richard Lee CC, Liao F, Singh SP, Zhang HH, Grinberg A, Love PE, Hwang ST, Farber JM: CCR6 is required for IL-23-induced psoriasis-like inflammation in mice. J Clin Invest 2009, I 19:2317-29.

FI000 Factor 6.0 Must Read

Evaluated by Michelle Lowes 0 I Oct 2009

28. Harper EG, Guo C, Rizzo H, Lillis JV, Kurtz SE, Skorcheva I, Purdy D, Fitch $E$, lordanov M, Blauvelt $A$ : Th 17 cytokines stimulate CCL20 expression in keratinocytes in vitro and in vivo: implications for psoriasis pathogenesis. J Invest Dermatol 2009, 129:2 I75-83.

FI000 Factor 3.0 Recommended

Evaluated by Stefan Martin OI Jun 2009

29. Papp KA, Langley RG, Lebwohl M, Krueger GG, Szapary P, Yeilding N, Guzzo C, Hsu MC, Wang Y, Li S, Dooley LT, Reich K; PHOENIX 2 study investigators: Efficacy and safety of ustekinumab, a human interleukin- $12 / 23$ monoclonal antibody, in patients with psoriasis: 52-week results from a randomised, double-blind, placebo-controlled trial (PHOENIX 2). Lancet 2008, 37I: 1675-84.

FI000 Factor 3.0 Recommended

Evaluated by Johann Gudjonsson 06 Jun 2008

30. Leonardi CL, Kimball AB, Papp KA, Yeilding N, Guzzo C, Wang Y, Li S, Dooley LT, Gordon KB: Efficacy and safety of ustekinumab, a human interleukin- /2/23 monoclonal antibody, in patients with psoriasis: 76-week results from a randomised, doubleblind, placebo-controlled trial (PHOENIX I). Lancet 2008, 37I:1665-74.

3I. Griffiths $C E$, Strober $B E$, van de Kerkhof $P$, Ho V, Fidelus-Gort R, Yeilding N, Guzzo C, Xia Y, Zhou B, Li S, Dooley LT, Goldstein NH, Menter A; ACCEPT Study Group: Comparison of ustekinumab and etanercept for moderate-to-severe psoriasis. $N$ Engl ] Med 362: | | $8-28$.

FI000 Factor 6.5 Must Read

Evaluated by Johann Gudjonsson 04 Feb 2010, David Hunter 10 Feb 2010, Robert Dawe 04 Mar 2010

32. Nograles KE, Zaba LC, Shemer A, Fuentes-Duculan J, Cardinale I, Kikuchi T, Ramon M, Bergman R, Krueger JG, Guttman-Yassky E: IL22-producing "T22" $T$ cells account for upregulated IL-22 in atopic dermatitis despite reduced IL-17-producing THI7 T cells. J Allergy Clin Immunol 2009, I 23: I244-52.e2. 